ROCZNIKI TEOLOGICZNE

Tom LXVI, zeszyt $10-2019$

DOI: http://dx.doi.org/10.18290/rt.2019.66.10-2

PIOTR WOŁOCHOWICZ

\title{
WSKAZANIA WYCHOWAWCZE ZAWARTE W DOKUMENTACH KOŚCIOŁA KATOLICKIEGO
}

\author{
INDICATIONS CONCERNING THE UPBRINGING OF CHILDREN PRESENTED \\ IN THE DOCUMENTS OF CATHOLIC CHURCH
}

\begin{abstract}
A b s t r a c t. The article discusses the most important indications concerning the upbringing of children presented in the Church documents from 1929 to 2016. The review is comprehensive, it includes the Catechism of the Catholic Church and the Code of Canon Law, the declaration of the Second Vatican Council Gravissimum educationis and papal encyclicals and exhortations: Divini illius Magistri by Pius XI, Humanae Vitae by Paul VI, Familiaris Consortio, Veritatis Splendor and Evangelium Vitae of John Paul II, Amoris Laetitia of Pope Francis. In addition to documents devoted entirely to the issue of education (GE, DIM), the ones that deal with the subject fragmentarily are discussed (FC, $\mathrm{AL}$ ) and also those that do not explicitly talk about upbringing, but the subject matter of basic values is indirectly a necessary call and educational guidelines (HV, VS, EV). Although they come from the period of nearly 90 years, there is a visible coherence of educational thought based on God's revelation. The synthesis of the subject seems especially necessary in the present times, when parents face completely new challenges when it comes to the broadly understood environment of raising their children.
\end{abstract}

Key words: children upbringing; family; values; faith.

Wskazania dotyczące wychowania dzieci przedstawione są w wielu dokumentach Kościoła. Poruszają je Katechizm Kościoła Katolickiego (KKK) (1992)

Dr Piотr WoŁochowicz - dr nauk teologicznych w zakresie teologii pastoralnej; Dyrektor Fundacji Misja Służby Rodzinie, www.msr.org.pl, ul. Dembego 12/13, 02-796 Warszawa; adres do korespondencji - jw.; e-mail: piotr.wolochowicz@msr.org.pl 
oraz Kodeks Prawa Kanonicznego (KPK) (1983). Z nauczania soborowego oraz papieskich encyklik i adhortacji należy wymienić chronologicznie następujące dokumenty: encyklika papieża Piusa XI o chrześcijańskim wychowaniu młodzieży Divini illius Magistri (DIM) (1929), deklaracja Soboru Watykańskiego II o wychowaniu chrześcijańskim Gravissimum educationis (GE) (1965), encyklika Pawła VI o zasadach moralnych w dziedzinie przekazywania życia ludzkiego Humanae vitae (HV) (1968), adhortacja Jana Pawła II o zadaniach rodziny chrześcijańskiej w świecie współczesnym Familiaris consortio (FC) (1981), encyklika Jana Pawła II o niektórych podstawowych problemach nauczania moralnego Kościoła Veritatis splendor (VS) (1993), encyklika Jana Pawła II o wartości i nienaruszalności życia ludzkiego Evangelium vitae (EV) (1995), posynodalna adhortacja apostolska papieża Franciszka o miłości w rodzinie Amoris laetitia (AL) (2016).

\section{FUNDAMENTY RODZICIELSKIEGO WYCHOWANIA (ZAWARTE W KKK, KPK, GE)}

\subsection{KATECHIZM KOŚCIOŁA KATOLICKIEGO (1994) I KODEKS PRAWA KANONICZNEGO (1984)}

Katechizm Kościoła katolickiego obowiązki rodziców określa w punktach 2221-2231. Wskazany jest tam szereg podstawowych faktów dotyczących wychowania: (1) troska rodziców ma obejmować „wychowanie moralne i formację duchową" (KKK 2221); (2) rodzice wychowują „,swe dzieci do wypełniania prawa Bożego" (KKK 2222); (3) dom rodzinny ma być miejscem „kształtowania cnót” (KKK 2223); (4) rodzice mają „zadanie i przywilej ewangelizowania swoich dzieci” (KKK 2225); (5) rodzice „powinni rozpocząć wychowanie do wiary od wczesnego dzieciństwa" (KKK 2226).

Kodeks Prawa Kanonicznego wskazuje, że: „Rodzice oraz ci, którzy ich zastępują, mają obowiązek i zarazem prawo wychowania potomstwa" (KPK 793, §1), przy czym dotyczy to nie tylko spraw doczesnych, ale i wiecznych: „Ponieważ prawdziwe wychowanie powinno objąć pełną formację osoby ludzkiej, zarówno w odniesieniu do celu ostatecznego, jak i w odniesieniu do dobra wspólnego społeczności, dlatego dzieci i młodzież tak winny być wychowywane, ażeby harmonijnie mogły rozwijać swoje przymioty fizyczne, moralne oraz intelektualne, zdobywać coraz doskonalszy zmysł odpowiedzialności, właściwie korzystać z wolności i przygotowywać się do czynnego udziału w życiu społecznym" (KPK 795).

Reasumując: Katechizm Kościoła Katolickiego oraz Kodeks Prawa Kanonicznego wyraźnie wskazują obowiązek rodziców co do świadomego i celowego 
wychowania dzieci. Podkreślają one, że w tym mieści się kształtowanie dobrego, solidnego człowieka tu na ziemi - jednak jako zasadniczą perspektywę wychowania chrześcijańskiego wskazują wieczność.

\author{
1.2. SOBÓR WATYKAŃSKI II: \\ DEKLARACJA O WYCHOWANIU CHRZEŚCIJAŃSKIM \\ GRAVISSIMUM EDUCATIONIS (1965)
}

Ogłoszenie na Soborze Watykańskim II dokumentu Deklaracja o wychowaniu chrześcijańskim jest sygnałem, że ojcowie soborowi widzieli potrzebę przypomnienia podstawowych zasad obowiązujących w sprawie wychowania. Już na samym początku określają, że dobrze pojęte wychowanie: ,[...] zdąża do kształtowania osoby ludzkiej w kierunku jej celu ostatecznego, a równocześnie do dobra społeczności, których człowiek jest członkiem i w których obowiązkach, gdy dorośnie, będzie brał udział" (GE 1).

Kolejny aspekt to obowiązek kształtowania do wartości, także w perspektywie duchowej: ,[...] dzieci i młodzież mają prawo, aby pobudzano ich do oceny wartości moralnych wedle prawidłowego sumienia i do przyjmowania owych wartości przez osobisty wybór, a również do doskonalszego poznawania i miłowania Boga” (GE 1). Warto zwrócić uwagę, że napisano tu „pobudzać”, a nie np. „nakazywać”. Pobudzanie oznacza uruchomienie czegoś, co Bóg w człowieka już włożył w dziele Stworzenia. Pobudzanie ma na celu, aby to „coś” zostało ożywione i mogło działać. Deklaracja podkreśla też, że młode pokolenie ma przyjmować te wartości przez „osobisty wybór” - zadaniem dla rodziców jest przekonać dzieci do wartości, by one same decydowały się na nie z wyboru, a nie z przymusu, strachu, przekupstwa itp.

Rodzice są w Bożym planie osobami przeznaczonymi do tego jako pierwsi i główni wychowawcy (GE 3). Ich zadanie zaczyna się od samego początku: „[...] należy już od najwcześniejszego wieku uczyć dzieci zgodnie z wiarą na chrzcie otrzymaną poznawania i czci Boga, a także miłowania bliźniego" (GE 3). Deklaracja podkreśla nie tylko nadrzędność ich misji wobec jakichkolwiek władz świeckich, ale wskazuje, że państwo powinno wspierać ich, szanując ich przekonania, i pochwala, gdy tak się dzieje (GE 7). Jednocześnie bardzo podkreśla, że Kościół sam ma użyczać rodzinom wszelkiej „pomocy duchowej” (GE 7).

Warto jeszcze nadmienić, że o przekazie wiary w rodzinie również wspomina soborowy Dekret o apostolstwie świeckich Apostolicam actuositatem (AA): "Chrześcijańscy małżonkowie są wzajemnie dla siebie, dla swoich dzieci i innych domowników współpracownikami łaski i świadkami wiary. Oni są dla swych 
dzieci pierwszymi głosicielami wiary i wychowawcami; słowem i przykładem przysposabiają je do życia chrześcijańskiego i apostolskiego [...]” (AA 11).

\section{WSKAZANIA WYCHOWAWCZE PRZEDSTAWIONE W ENCYKLIKACH}

\subsection{PIUS XI: ENCYKLIKA O CHRZEŚCIJAŃSKIM WYCHOWANIU MŁODZIEŻY DIVINI ILLIUS MAGISTRI (1929)}

Encyklika Divini illius Magistri niesie bardzo głębokie treści, i - gdy patrzymy na nią z perspektywy dziewięćdziesięciu lat później - zadziwia swoją aktualnością. Jak zauważa Stanisław Dziekoński w publikacji Pius XI papież doktryny wychowawczej Kościoła problematyka wychowania w refleksji Kościoła: ,[...] nabrała jeszcze pewnej dynamiki rozwoju w wiekach XIX i XX, przede wszystkim pod wpływem pewnych przeobrażeń kulturowych i społecznych. $\mathrm{Na}$ gruncie pedagogiki światowej pojawiły się nowe prądy i kierunki w niektórych przypadkach całkowicie sprzeczne z ideowymi i teoretycznymi podstawami chrześcijańskiego wychowania, jak też z praktyką wychowawczą lansowaną przez Kościół"'. To jest powód dlaczego głos podejmowali papieże Pius IX, Leon XIII i Pius $X^{2}$. Ukoronowaniem i przedstawieniem całościowej koncepcji jest encyklika Divini illius Magistri. Poniżej przedstawiony zostanie przegląd jej najważniejszych treści.

Po pierwsze - wyraźnie określony jest dwutorowy cel wychowania, zarówno wieczny, jak i doczesny. Wychowanie: ,[...] ostatecznie do tego zmierza, by zapewnić duszom wychowanków najwyższe dobro - Boga, i ludzkiej społeczności najwyższy stopień możliwego na tej ziemi dobrobytu” (DIM, s. 5) ${ }^{3}$. Priorytetem jest jednak kształtowanie duchowe: „Właściwym i bezpośrednim celem chrześcijańskiego wychowania jest współdziałać z łaską Bożą w urabianiu prawdziwego i doskonałego chrześcijanina" (DIM, s. 42). Drogą zaś do tego jest ukierunkowana strategicznie praca nad młodym człowiekiem: „Trzeba zatem poprawić nieuporządkowane skłonności, wzmacniać i zestrajać dobre od lat

S. DzIEKońSKI, Pius XI papież doktryny wychowawczej Kościoła, w: Wychowanie w wierze w kontekście przemian wspótczesności, red. R. Buchta, S. Dziekoński, [Seria: Studia i Materiały Wydziału Teologicznego Uniwersytetu Śląskiego w Katowicach, nr 61, red. A. Malina], Katowice: Księgarnia św. Jacka 2011, s. 28.

${ }^{2}$ Por. tamże, s. 28-30.

${ }^{3}$ Dokument nie jest podzielony na punkty, podawane są więc strony według wydania: Pıus XI, Encyklika „Divini illius Magistri” o chrześcijańskim wychowaniu młodzieży (31.12.1929), [Seria: Magisterium Kościoła Katolickiego], Warszawa: Wydawnictwo Te Deum 1999. 
najmłodszych, a przede wszystkim należy oświecać rozum i wzmacniać wolę za pomocą prawd nadprzyrodzonych i środków łaski” (DIM, s. 27).

Po drugie - to rodzina została powołana jako naturalne środowisko do tego procesu: „Pierwszym, naturalnym i koniecznym środowiskiem jest rodzina, właśnie do tego przez Stwórcę przeznaczona. Stąd normalnie najskuteczniejsze i najtrwalsze wychowanie jest to, które się otrzymuje w dobrze urządzonej i karnej rodzinie chrześcijańskiej, tym bardziej skuteczne, im jaśniej i trwalej przyświeca tam dobry przykład, przede wszystkim rodziców i innych domowników” (DIM, s. 32). Pius XI sprzeciwia się poglądowi, że to państwo ma prawo do wychowania dziecka. Uzasadnia to prosto: „Nie zwraca się na to uwagi, że, by być obywatelem państwa, człowiek najpierw musi istnieć, a istnienia nie ma on od państwa, ale od rodziców" (DIM, s. 15). Pius XI domaga się, by państwo chroniło ,wychowanie moralne i religijne młodzieży, usuwając wrogie mu publiczne przeszkody" (DIM, s. 20).

Trzeci element, mocno podkreślany w encyklice, to sprawa fundamentalnego sposobu patrzenia na wychowanie. Pius XI obala mit, że dobre wychowanie da się uzyskać w sposób jedynie ludzki. Wskazuje, że współcześnie wielu ludzi: „[...] spodziewa się, że wychowanie będą mogli wydobyć z samej ludzkiej natury i urzeczywistnić wyłącznie własnymi siłami. Niestety w tym błądzą, bo zamiast kierować dążenia do Boga, pierwszego początku i ostatniego celu wszechświata, cofają się i zatrzymują na sobie samych, przywiązując się wyłącznie do rzeczy ziemskich i doczesnych" (DIM, s. 4). Wyjaśniając to, dalej wskazuje dwa z błędnych systemów pedagogicznych: „Fałszywym przeto jest wszelki naturalizm pedagogiczny, który w kształceniu młodzieży w jakikolwiek sposób wyklucza albo ogranicza nadprzyrodzone chrześcijańskie wyrobienie; błędną też jest wszelka metoda wychowania, która się opiera w całości lub w części na zaprzeczeniu grzechu pierworodnego i łaski, albo zapomnieniu o nich, a stąd na samych tylko siłach ludzkich natury" (DIM, s. 28).

Jako czwarty obszar encyklika demaskuje fałszywe pojęcie wolności: „Sromotnie się łudzą, sądząc, że wyzwalają, jak mówią, dziecko. Przeciwnie! Czynią je raczej niewolnikiem swojej ślepej pychy i swoich nie uporządkowanych namiętności, bo siłą logicznego następstwa tych błędnych systemów, usprawiedliwia się owe namiętności jako słuszne wymagania natury, posiadającej tzw. autonomię" (DIM, s. 29). Pius XI wskazuje także, że te błędne drogi wychowania grożą szczególnie niebezpiecznymi konsekwencjami w obszarze ludzkiej seksualności, czyli po prostu demoralizacją: „Najbardziej wszakże niebezpiecznym jest ów naturalizm, który w naszych czasach przenika dziedzinę wychowania w materii najbardziej delikatnej, jaką jest czystość obyczajów" (DIM, s. 29). 
Encyklika nawiązuje do postaci kardynała Sylwiusza Antoniano (1540-1603) i napisanego przez niego traktatu $O$ chrześcijańskim wychowaniu dzieci ${ }^{4}$. Dzieło to św. Karol Boromeusz kazał publicznie czytać zebranym w kościołach rodzicom (DIM, s. 32). Kardynał Antoniano podkreślał, że w kościelnej wizji wychowania automatycznie mieści się bycie uczciwym człowiekiem i dobrym obywatelem: „Zatem bardzo błądzą ci, co rozdzielają rzeczy tak bardzo ze sobą złączone, i co sądzą, że będą mogli mieć dobrych obywateli, za pomocą innych praw i na innych drogach, jak te, co sprzyjają wyrobieniu dobrego chrześcijanina” (DIM, s. 25).

Pius XI apelował więc do duchownych: „Dlatego zaklinamy Pasterzy dusz, na wnętrzności Jezusa Chrystusa, by użyli wszystkich środków w naukach i katechizmach i by słowem i pismami, szeroko rozrzucanymi, przypominali chrześcijańskim rodzicom ich najważniejsze obowiązki i przedstawiali nie tyle teoretycznie lub ogólnikowo, ile praktycznie i w szczegółach, ich pojedyncze obowiązki w zakresie religijnego, moralnego i obywatelskiego wychowania dzieci" (DIM, s. 33).

\subsection{PAWEŁ VI: ENCYKLIKA HUMANAE VITAE O ZASADACH MORALNYCH W DZIEDZINIE PRZEKAZYWANIA ŻYCIA LUDZKIEGO (1968)}

Encyklika Humanae vitae nie mówi bezpośrednio o wychowaniu. Jednak dotyczy ona obszaru, gdzie ludzkie zachowania są najbardziej wrażliwe na przyjęty system wartości, wynikający z wychowania - w przekazywaniu życia (szerzej: w sprawach płodności).

Paweł VI wskazuje nowe wyzwania, przed jakimi stoją małżonkowie: „Jeżeli w każdej epoce pełnienie tego obowiązku stawiało przed sumieniem małżonków trudne problemy, to współczesny rozwój społeczeństwa ludzkiego spowodował takie przemiany, że powstały nowe zagadnienia, których Kościołowi nie wolno pomijać milczeniem, ponieważ odnoszą się one do spraw tak ściśle związanych z życiem i szczęściem ludzi” (HV 1). W ciągu pięćdziesięciu lat, które upłynęły, tych przemian i nowych zagadnień pojawiło się wiele więcej.

Większość katolickich ekspertów zalecała dopuszczenie używania antykoncepcji, jednak Paweł VI stanął na straży wartości, które nie podlegają zmianie. Humanae vitae jest przykładem precyzyjnego wykładu na bardzo trudny temat

${ }^{4}$ S. Antoniano, Dell'Educazione Cristiana e Politica de' Figliuoli (...), s. 1, Milano: Tipi di Giuseppe Pogliani 1821; https://archive.org/details/DelleducazioneCristianaEPoliticaDeFigliuoli (dostęp: 21.12.2018). 
- wykładu, wobec którego muszą ustąpić różnego rodzaju wątpliwości czy argumenty za kompromisem (HV 3; HV 14).

Papież VI stawia wprost niełatwe pytanie: „czy, biorąc pod uwagę zarówno warunki współczesnego życia, jak i znaczenie stosunków małżeńskich dla harmonii i wzajemnej wierności między małżonkami, nie należałoby poddać rewizji obowiązujących dotąd zasad moralnych, szczególnie jeżeli się zważy, że można je zachować tylko za cenę wielkich, niekiedy heroicznych poświęceń?" (HV 3). Dalej zaś odpowiada, że jedynym dobrym wyjściem jest właśnie respektowanie Bożych wartości: „Problem przekazywania życia, podobnie jak każdy inny problem dotyczący życia ludzkiego, powinien być tak rozpatrywany, aby - poza aspektami cząstkowymi, należącymi do porządku biologicznego, psychologicznego, demograficznego czy socjologicznego - uwzględnił całego człowieka i całe jego powołanie, obejmujące nie tylko porządek naturalny i doczesny, ale również nadprzyrodzony i wieczny" (HV 7).

Podstawą odpowiedzi na praktyczne problemy są zamierzone w Bożym planie cechy i wymogi miłości małżeńskiej. Ma ona być: (1) ludzka, czyli zarazem zmysłowa i duchowa; (2) pełna, tzn. kochać współmałżonka dla niego samego; (3) wierna i wyłączna aż do końca życia; (4) płodna, ku wzbudzeniu nowego życia (HV 9). Odpowiedzialne rodzicielstwo harmonijnie uwzględnia rzeczywistość wewnętrznych motywacji, procesy biologiczne, opanowanie przez rozum i wolę wrodzonych popędów i namiętności oraz warunki fizyczne, ekonomiczne, psychologiczne i społeczne (HV 10).

Paweł VI wskazuje na wartość uczenia się panowania nad sobą w okresach płodnych (jeśli para małżeńska aktualnie nie planuje począć dziecka): „Jednakże to opanowanie, w którym przejawia się czystość małżeńska, nie tylko nie przynosi szkody miłości małżeńskiej, lecz wyposaża ją w nowe ludzkie wartości. Wymaga ono wprawdzie stałego wysiłku, ale dzięki jego dobroczynnemu wpływowi małżonkowie rozwijają w sposób pełny swoją osobowość, wzbogacając się o wartości duchowe" (HV 21). Oprócz wartości, jakie to opanowanie niesie małżonkom, Paweł VI podkreślił więc także wpływ wychowawczy na dzieci wynikający ze stosowania naturalnego planowania rodziny ${ }^{5}$.

Opisana przez Pawła VI wartość realizacji zasad moralnych w relacji małżeńskiej i rodzicielskiej potwierdza świadectwo trwającego ponad 34 lata małżeństwa Autora artykułu i jego śp. żony Marioli (†2016), w którym nigdy nie stosowali oni żadnej antykoncepcji. Pozytywnym rezultatem były ich wzajemne odniesienia jako małżonków, zaś dzieci całkiem naturalnie i bez problemów przyjęły pozytywne postawy wobec naturalnego planowania rodziny i ujmowania rzeczywistości zgodnie z Bożymi normami moralnymi. 


\subsection{JAN PAWEŁ II: ENCYKLIKA VERITATIS SPLENDOR \\ O NIEKTÓRYCH PODSTAWOWYCH PROBLEMACH \\ NAUCZANIA MORALNEGO KOŚCIOŁA (1993)}

Treści zawarte w Veritatis splendor mają bezpośredni związek z wychowaniem. Dają one perspektywę właściwego spojrzenia na wartości moralne w świetle niezmiennej Bożej prawdy. Papież odwołuje się do wersetu „Poznacie prawdę, a prawda was wyzwoli” (J 8,32). Następująco streszcza Bożą prawdę o człowieku: „Powołani do zbawienia poprzez wiarę w Jezusa Chrystusa, 'światłość prawdziwą, która oświeca każdego człowieka' (J 1,9), ludzie stają się 'światłością w Panu' i 'dziećmi światłości' (por. Ef 5,8) i uświęcają się przez 'posłuszeństwo prawdzie' (por. 1 P 1,22)” (VS 1). Encyklika podkreśla niezmienność podstawowych wartości: „Reguły moralne, które Bóg nadał w Starym Przymierzu i które w Nowym i Wiecznym Przymierzu osiągnęły doskonałość w osobie Wcielonego Syna Bożego, muszą być wiernie strzeżone i nieustannie wypetniane w różnych kulturach powstających w ciągu dziejów" (VS 25), i wskazuje na obowiązek zachowania depozytu wiary i moralności przez Kościół (VS 27).

Wobec współczesnych wyzwań wychowawczych Veritatis splendor jest dla rodziców i wszystkich wychowawców nieocenioną pomocą. Szczególnie wart zauważenia jest rozdział drugi, odwołujący się do wersetu „Nie bierzcie więc wzoru z tego świata" (Rz 12,2). Jan Paweł II pokazuje tam właściwą ocenę niektórych tendencji współczesnej teologii moralnej, widząc potrzebę, by: „,...] zwrócić uwagę na te elementy doktryny moralnej Kościoła, które wydają się dziś najbardziej narażone na błędne, wieloznaczne interpretacje lub na zapomnienie" (VS 30). Jako oś problemów z praktycznymi wnioskami odnoszonymi do moralności papież widzi analizę pojęcia wolności (VS 31). Przenosi się to bezpośrednio na błędne, bo subiektywne i nieoparte na prawdzie obiektywnej, podejście do sumienia: „Sumieniu indywidualnemu przyznaje się prerogatywy najwyższej instancji osądu moralnego, która kategorycznie i nieomylnie decyduje o tym, co jest dobre, a co złe. Do tezy o obowiązku kierowania się własnym sumieniem niesłusznie dodano tezę, wedle której osąd moralny jest prawdziwy na mocy samego faktu, że pochodzi z sumienia. Wskutek tego zanikł jednak nieodzowny wymóg prawdy, ustępując miejsca kryterium szczerości, autentyczności, 'zgody z samym sobą', co doprowadziło do skrajnie subiektywistycznej interpretacji osądu moralnego" (VS 32).

Jan Paweł II opisuje błędny mechanizm podejścia do roli i miejsca ludzkiego rozumu: „Ponieważ jednak zapomniano o zależności rozumu od Mądrości Bożej oraz o konieczności - w obecnym stanie upadłej natury - Bożego Objawienia w poznaniu prawd moralnych, także tych, które należą do porządku naturalnego, doszło do powstania teorii całkowitej suwerenności rozumu $\mathrm{w}$ dziedzinie 
norm moralnych służących właściwemu uporządkowaniu życia w tym świecie. [...] Otóż te właśnie kierunki myślowe doprowadziły do negacji prawdy - zawartej w Piśmie Świętym i w niezmiennym nauczaniu Kościoła - iż naturalne prawo moralne ma Boga za twórcę i że człowiek przez swój rozum uczestniczy w odwiecznym prawie, którego sam nie ustanawia" (VS 36). Dla rodziców wychowujących dzieci bardzo ważne są słowa o konieczności trwania przy wartościach: „Stanowczość, z jaką Kościół broni uniwersalnych i niezmiennych norm moralnych, nie ma bynajmniej na celu umniejszać człowieka, ale służyć jego prawdziwej wolności" (VS 96). Tak samo w procesie wychowania dziecka rodzic ma bronić obiektywnych i niezmiennych wartości oraz norm moralnych - i to będzie służyło prawdziwej wolności tego dziecka.

Jan Paweł II silnie podkreśla prawdę o tożsamości człowieka wierzącego i co z tego wynika dla codziennego życia: „Chrystus nas odkupit! Znaczy to, że obdarzył nas możliwościq realizacji całej prawdy naszego istnienia; że wyzwolił naszą wolność spod władzy pożądania. Skoro więc odkupiony człowiek wciąż grzeszy, nie świadczy to o niedoskonałości Chrystusowego aktu odkupienia, ale o woli człowieka, chcącej wymknąć się łasce, jaka płynie z tego aktu. Przykazanie Boga jest na pewno proporcjonalne do zdolności człowieka, ale do zdolności człowieka obdarowanego Duchem Świętym; człowieka, który nawet jeśli zgrzeszył, zawsze może otrzymać przebaczenie i cieszyć się obecnością Ducha Świętego" (VS 103). To jest bardzo ważne przesłanie do przekazania przy wychowaniu dzieci, gdyż mówi o tym, że życie w zgodzie z Bożymi wartościami jest możliwe, i to nie ze względu na naszą siłę, ale dzięki temu, co uczynił dla nas Chrystus.

\subsection{JAN PAWEŁ II: ENCYKLIKA EVANGELIUM VITAE O WARTOŚCI I NIENARUSZALNOŚCI ŻYCIA LUDZKIEGO (1995)}

Ważne treści, które powinny być wykorzystywane przy wychowaniu dzieci, przynosi encyklika Evangelium vitae. Przede wszystkim potwierdza ona, że każdy człowiek otwarty na prawdę i dobro może rozpoznać: „świętość ludzkiego życia od poczęcia aż do kresu oraz dojść do przekonania, że każda ludzka istota ma prawo oczekiwać absolutnego poszanowania tego swojego podstawowego dobra. [...] Obrońcami i rzecznikami tego prawa powinni być w sposób szczególny wierzący w Chrystusa" (EV 2). Jednak obecnie świętość ta jest podważana w imię prawa do indywidualnej wolności (EV 4).

Jan Paweł II wskazuje na współczesne zjawiska zagrożenia życia z różnych stron: antykoncepcja, która często prowadzi do aborcji (EV 13), techniki sztucznej reprodukcji i badania prenatalne służące eugenice, a nawet koncepcje dzieciobójstwa 
(EV 14) oraz eutanazję (EV 15). Dlatego papież wzywa do głoszenia Ewangelii życia jako części Ewangelii Chrystusa (EV 78). Oczywiście nie chodzi o to, aby głosić Ewangelię życia zamiast Dobrej Nowiny o Zbawieniu w Chrystusie, jednak: „Obrona i promocja życia ludzkiego jest przejawem uczestnictwa w misji królewskiej Chrystusa" (EV 87). Kształtowanie w dzieciach poszanowania ludzkiego życia od poczęcia do naturalnej śmierci jest jednym z kluczowych obszarów wychowania, jednak musi być oparte najpierw na osobistej relacji z Bogiem.

\section{WSKAZANIA WYCHOWAWCZE PRZEDSTAWIONE W ADHORTACJACH}

\subsection{JAN PAWEŁ II: ADHORTACJA FAMILIARIS CONSORTIO \\ O ZADANIACH RODZINY CHRZEŚCIJAŃSKIEJ \\ W ŚWIECIE WSPÓŁCZESNYM (1981)}

Familiaris consortio szeroko omawia podstawowe aspekty funkcjonowania rodziny w zamyśle Bożym. Jan Paweł II wyraźnie podkreśla potrzebę aksjologicznego ukształtowania człowieka: „Posiadanie właściwego spojrzenia na porządek moralny, na jego wartości i normy jest zawsze rzeczą wielkiej wagi; jest zaś szczególnie ważne, gdy wzrastają i mnożą się trudności w ich zachowaniu" (FC 34). Mówiąc o wychowaniu dzieci, potwierdza prawo i obowiązek rodziców do wychowania, jako coś niezbywalnego, pierwotnego i mającego priorytet wobec wszelkich innych relacji wobec dziecka (FC 36).

Adhortacja w numerze 37, zatytułowanym „Wychowanie do istotnych wartości życia ludzkiego", podaje fundamentalne treści: (1) zadanie wychowania aksjologicznego w rodzinie jest niezwykle ważne i konieczne do wykonania, nawet gdy są przeciwności: „Pomimo często bardzo poważnych dziś trudności w dziele wychowania, rodzice winni ufnie i z odwagą kształtować w dzieciach istotne wartości życia ludzkiego" (FC 37); (2) istnieją trudności zewnętrzne, jakie przeżywa współczesna rodzina: „W społeczeństwie wstrząsanym i rozbitym przez napięcia i konflikty, wynikające z gwałtownego ścierania się różnych indywidualizmów i egoizmów, dzieci powinny nabyć nie tylko poczucie prawdziwej sprawiedliwości, która jedyna prowadzi do poszanowania godności osobistej każdego człowieka, ale także i tym bardziej poczucie prawdziwej miłości, jako postawy szczerej troski i bezinteresownej służby wobec drugich [...]" (FC 37); (3) fundamentalną dla całego życia rodzinnego jest postawa wzajemnej miłości męża i żony: „Dar z siebie, który ożywia wzajemną miłość małżonków, staje się wzorem i zasadą składania daru z siebie, co powinno dokonywać się we wzajemnych stosunkach braci i sióstr oraz różnych, współżyjących w rodzinie pokoleń” 
(FC 37); (4) miłość rodziców daje możliwość we właściwy sposób kształtować dzieci w sferach najdelikatniejszych: „Wychowanie do miłości pojętej jako dar z siebie stanowi nieodzowną przesłankę dla rodziców wezwanych do przekazania dzieciom jasnego i subtelnego wychowania seksualnego" (FC 37); (5) to rodzice mają pełny autorytet nad tym, jak ich dzieci będą formowane w dziedzinie płciowości: „Wychowanie seksualne, stanowiące prawo i podstawowy obowiązek rodziców, winno dokonywać się zawsze pod ich troskliwym kierunkiem zarówno w domu, jak i w wybranych i kontrolowanych przez nich ośrodkach wychowawczych" (FC 37); (6) takie kształtowanie pozwoli na zachowanie skarbu czystości seksualnej: „W tym kontekście bezwzględnie nieodzowne jest wychowanie do czystości, jako cnoty, która doprowadza osobę do prawdziwej dojrzałości i uzdalnia ją do szanowania i rozwijania 'oblubieńczego sensu' ciała" (FC 37); (7) ta czystość nie wynika z systemu zakazów, ale z zasad moralnych i głębokiego przekonania o wartości takiej drogi życiowej: „Ze względu na powiązania zachodzące pomiędzy wymiarem płciowym osoby a jej wartościami etycznymi, wychowanie ma doprowadzić do znajomości zasad moralnych i uznania ich za konieczną i cenną gwarancję odpowiedzialnego wzrostu osobowego w dziedzinie płciowości ludzkiej" (FC 37).

Familiaris consortio bardzo wyraźnie stawia konkretne zadanie dla rodziców: „Misja wychowawcza wymaga, ażeby rodzice chrześcijańscy ukazali dzieciom wszystkie te treści, które są konieczne do stopniowego dojrzewania ich osobowości z punktu widzenia chrześcijańskiego i kościelnego" (FC 39). To jednak nie wszystko, dalej czytamy, że rodzice mają się zatroszczyć, by: „[...] pokazać dzieciom, do jakich głębin prowadzi wiara i miłość Jezusa Chrystusa” (FC 39). Wskazanie, że rodzice mają dzieciom pokazywać głęboką, dojrzałą wiarę i miłość, a nie po prostu powierzchowne informacje o Bogu, ma szczególne znaczenie wychowawcze. Pokazanie wiary jako skarbu, poprowadzenie ich aż do „głębin” daje możliwość skutecznego wpojenia tych wartości (zgodnie z tekstem Pwt 6,7). Jednym z filarów tego procesu jest motywacja, kto dał to zadanie i jak wielka jest godność samego dziecka: „świadomość, że Pan powierza im troskę o wzrost dziecka Bożego [...]” (FC 39).

\subsection{FRANCISZEK - ADHORTACJA AMORIS LAETITIA \\ O MIŁOŚCI W RODZINIE (2016)}

Rozdział 7 adhortacji podejmuje sprawę wychowania. Tytuł „Umocnić wye chowanie dzieci" wskazuje, że papież Franciszek diagnozuje stan współczesnego wychowania jako zdecydowanie niesatysfakcjonujący. 
W punkcie 259 papież uświadamia rolę rodziców, którzy: ,[...] zawsze wpływają na rozwój moralny swoich dzieci, na dobre i na złe. Dlatego najlepiej, jeśli zaakceptują tę nieuniknioną odpowiedzialność i wypełniają ją świadomie, entuzjastycznie, rozsądnie i we właściwy sposób" (AL 259). Współczesna kultura podważa te prawdy: odmawia rodzicom wychowawczego wpływu, próbuje ich zniechęcić do akceptacji odpowiedzialności. Wielu rodziców wychowuje więc dzieci mało świadomie, zupełnie nieentuzjastycznie, mało rozsądnie i w niewłaściwy sposób. Franciszek wskazuje: „Rodzina nie może zrezygnować [...]” (AL 260). W dalszych punktach porusza szereg ważnych zagadnień.

Etyczna edukacja dzieci. Adhortacja wskazuje, że: „Rozwój emocjonalny i etyczny osoby wymaga fundamentalnego doświadczenia: przekonania, że nasi rodzice są godni zaufania" (AL 263). Wydaje się, że współcześnie coraz częściej bywa nie tylko tak, że rodzice rzeczywiście zawiodą zaufanie dziecka - ale wręcz toczy się walka o to, by zburzyć to zaufanie nawet wobec rodziców naprawdę jego godnych.

Kolejna myśl dotyczy tego, co obejmuje zadanie rodziców: „, [...] wychowanie woli oraz rozwijanie dobrych nawyków i emocjonalnych skłonności ku dobru" (AL 264); czyli nie tylko stawianie normy, ale ukierunkowanie woli dziecka, ćwiczenie go w tym i wprowadzanie w identyfikację emocjonalną.

Dyscyplina w wychowaniu. Franciszek zdecydowanie opowiada się za koniecznością dyscypliny, jednak we właściwy sposób: „Napomnienie jest bodźcem, jeśli równocześnie docenia się i uznaje wysiłki oraz kiedy dziecko odkrywa, że jego rodzice podtrzymują cierpliwą ufność. [...] Dziecko, które popełnia zły czyn, musi być napomniane, ale nigdy jako wróg czy ktoś na kim rozładowywana jest własna agresywność" (AL 269). Papież przeciwstawia się koncepcji wychowania bezstresowego, przypomina o konieczności łączenia dyscypliny z miłością. Poza tym zwraca uwagę, że „[...] osoba dorosła powinna uznać, że niektóre występki związane są z kruchością i ograniczeniami właściwymi wiekowi (AL 269). Przypomina to klasyczne sformułowanie z rachunku sumienia w Mszale Rzymskim z roku 1963, by odróżniać „prawdziwe przewiny od płochości dziecięcej”.

Realistyczne wymagania. Franciszek postuluje jako normalną drogę „proponowanie małych kroków", gdyż „domagając się zbyt wiele, nic się nie zyska" (AL 271). Wskazuje podstawowe zagrożenie wynikające z niezachowania tej zasady: „Osoba, skoro tylko będzie mogła uwolnić się od władzy, prawdopodobnie przestanie dobrze czynić" (AL 271). Uzasadnione jest więc kształtowanie w dzieciach takiej postawy, żeby nawet bez bezpośredniego nadzoru postępowały

${ }^{6}$ Mszał Rzymski, tł. i objaśnienia O.O. Benedyktyni z Opactwa Tynieckiego, red. S. Kaźmierczak, Poznań: Pallottinum 1963, s. 1356. 
tak samo jak w obecności rodziców. Oczywiście ojciec i matka sami też muszą dawać dzieciom przykład, że trwają przy wartościach i przekonaniach niezależnie od okoliczności, czy okazji do złego.

Adhortacja sygnalizuje jeszcze inne zagrożenie: „Spotkanie edukacyjne między rodzicami a dziećmi może być ułatwione lub utrudnione przez coraz bardziej zaawansowane technologie komunikacji i rozrywki. [...] Wiemy, że czasami te środki oddalają, a nie zbliżają, jak na przykład, kiedy w porze posiłku każdy zajmuje się swoim telefonem komórkowym lub kiedy jedno z małżonków zasypia, czekając na drugiego, który spędza całe godziny przy jakimś urządzeniu elektronicznym" (AL 278).

Sprawa edukacji seksualnej. Tytuł podrozdziału adhortacji brzmi: „'Tak' dla edukacji seksualnej”. W Polsce określenie to może rodzić nieporozumienia, bowiem odróżniamy „edukację seksualną” od „wychowania seksualnego”. W naszym kraju przyjęło się oparte na wartościach określenie „Przygotowanie do życia w rodzinie”. Pisanie w adhortacji o „edukacji seksualnej” jest zrozumiałe w odniesieniu do terminologii: edukacja seksualna typu A, B, C. Opisane treści odpowiadają edukacji typu A, czyli opartej na czystości przed ślubem.

Papież formułuje tu m.in. kilka kluczowych myśli: (1) „Informacja musi docierać w odpowiednim czasie oraz w sposób stosowny do przeżywanego etapu" (AL 281); (2) „Wielką wartość ma taka edukacja seksualna, która pielęgnuje zdrową skromność, chociaż niektórzy utrzymują, że to sprawa z innych czasów" (AL 282); (3) „Często edukacja seksualna skupia się na zachęcie do 'zabezpieczenia', dążąc do 'bezpiecznego seksu”" (AL 283).

Franciszek podkreśla, by w procesie wychowania dzieci ,[...] nauczyć drogi prowadzącej przez różne przejawy miłości, wzajemnej troski, szacunku naznaczonego czułą troską, bogatego w znaczenia komunikowania się. Wszystko to przygotowuje bowiem do pełnego i hojnego daru z siebie, który wyrazi się po ślubie w darze ciał. Zjednoczenie seksualne w małżeństwie przejawi się wówczas jako znak zaangażowania całościowego, ubogaconego całą wcześniejszą drogą" (AL 283) ${ }^{7}$.

Przekazywanie wiary. Franciszek zwraca uwagę na szczególnie trudną sytuację współczesnego przekazu wiary dzieciom, ale wzywa, by nie rezygnować: „Wychowanie dzieci powinno być naznaczone procesem przekazywania wiary, który napotyka na trudności ze względu na aktualny styl życia, godziny pracy

${ }^{7}$ Skuteczność takiego oddziaływania potwierdzają własne doświadczenia rodzinne Autora artykułu, a zwłaszcza wychowanie dzieci owocujące zachowaniem przez nie czystości i późniejszym przyjmowaniu sakramentu małżeństwa z pełną czystością myśli i ciała. 
oraz złożoność dzisiejszego świata" (AL 287). Oznacza to, że rodzice świadomi specyfiki czasów, w jakich żyją, muszą dawać sobie radę pomimo tego.

\section{ZAKOŃCZENIE}

Praktyczne podsumowanie wizji wychowawczej podane zostało w przemówieniu Jana Pawła II w Zakopanem (1997). Zwracając się do rodziców dzieci pierwszokomunijnych, powiedział: „To rodzice w pierwszym rzędzie mają prawo i obowiązek wychowywać swoje dzieci, zgodnie z własnymi przekonaniami. Nie oddajcie tego prawa instytucjom, które mogą przekazać dzieciom i młodzieży niezbędną wiedzę, ale nie są w stanie dać im świadectwa wiary, świadectwa rodzicielskiej troski i miłości. Nie dajcie się zwieść pokusie zapewniania potomstwu jak najlepszych warunków materialnych za cenę waszego czasu i uwagi, które są mu potrzebne do wzrastania w 'mądrości, w latach i w łasce u Boga i u ludzi' (Łk 2,52). Jeśli chcecie - wy, rodzice - obronić wasze dzieci przed demoralizacją, przed duchową pustką, jakie proponuje świat przez różne środowiska, a nawet szkolne programy, otoczcie te dzieci ciepłem waszej rodzicielskiej miłości i dajcie im przykład chrześcijańskiego życia"».

Słowa Jana Pawła II stanowią esencjonalne streszczenie najważniejszych faktów, jakich rodzice powinni być świadomi - a jednocześnie wskazują im konkretne kierunki działania. Po dalszych dwudziestu latach widać, że one są coraz bardziej aktualne.

\section{BIBLIOGRAFIA}

Antoniano S., Dell'Educazione Cristiana e Politica de' Figliuoli (...), s. 1, Milano: Tipi di Giuseppe Pogliani 1821; https://archive.org/details/DelleducazioneCristianaEPoliticaDeFigliuoli (dostęp: 21.12.2018).

DzIEKoŃSKi S., Pius XI papież doktryny wychowawczej Kościoła, w: Wychowanie w wierze w kontekście przemian współczesności, red. R. Buchta, S. Dziekoński, [Seria: Studia i Materiały Wydziału Teologicznego Uniwersytetu Śląskiego w Katowicach, nr 61, red. A. Malina], Katowice: Księgarnia św. Jacka 2011, s. 27-40.

Franciszer, Posynodalna adhortacja apostolska Amoris laetitia o miłości w rodzinie (19.03.2016), Częstochowa: Edycja Świętego Pawła 2016.

8 Jan Pawee II, Pan Jezus was kocha, Przemówienie do dzieci pierwszokomunijnych w kościele Świętej Rodziny w Zakopanem (7.06.1997), „L'Osservatore Romano” [wyd. pol.] 18(1997), nr 7(194), s. 50. 
JAN PAWE€ II, Adhortacja apostolska Familiaris consortio o zadaniach rodziny chrześcijańskiej w świecie współczesnym (22.11.1981), Watykan: Drukarnia Watykańska „Polyglotta” 1981.

JAN PAWEe II, Encyklika Veritatis splendor o niektórych podstawowych problemach nauczania moralnego Kościoła (6.08.1993), Poznań: Pallottinum 2003.

JAN PAWEe II, Encyklika Evangelium vitae o wartości i nienaruszalności życia ludzkiego (25.03.1995), Katowice: Drukarnia Archidiecezjalna w Katowicach 1995.

Jan Pawee II, Pan Jezus was kocha. Przemówienie do dzieci pierwszokomunijnych w kościele Świętej Rodziny w Zakopanem (7.06.1997), „L'Osservatore Romano” [wyd. pol.] 18(1997), nr 7(194), s. 50.

Katechizm Kościoła Katolickiego, Poznań: Pallottinum 1994.

Kodeks Prawa Kanonicznego. Przekład polski zatwierdzony przez Konferencję Episkopatu, tł. E. Sztafrowski, red. K. Dynarski, Poznań: Pallotinum 1984.

Mszał Rzymski, tł. i objaśnienia O.O. Benedyktyni z Opactwa Tynieckiego, red. S. Kaźmierczak, Poznań: Pallottinum 1963.

PAWEŁ VI, Encyklika Humanae vitae o zasadach moralnych w dziedzinie przekazywania życia ludzkiego (25.07.1968), Wrocław: Wydawnictwo TUM 1999.

Pius XI, Encyklika Divini illius Magistri o chrześcijańskim wychowaniu młodzieży (31.12.1929), [Seria: Magisterium Kościoła Katolickiego], Warszawa: Wydawnictwo Te Deum 1999.

Sobór WATYKaŃSKi II, Deklaracja o wychowaniu chrześcijańskim Gravissimum educationis (28.10.1965), w: Sobór Watykański II, Konstytucje. Dekrety. Deklaracje, wyd. 3, Poznań: Pallottinum 1986, s. 313-324.

SobóR WATYKAŃSKi II, Dekret o apostolstwie świeckich Apostolicam actuositatem (18.11.1965), w: Sobór Watykański II, Konstytucje. Dekrety. Deklaracje, wyd. 3, Poznań: Pallottinum 1986, s. 379-405.

\author{
WSKAZANIA WYCHOWAWCZE ZAWARTE \\ W DOKUMENTACH KOŚCIOŁA KATOLICKIEGO
}

\title{
Streszczenie
}

Artykuł omawia najważniejsze wskazania dotyczące wychowania dzieci przedstawione w dokumentach Kościoła od roku 1929 do 2016. Przegląd jest wyczerpujący, uwzględnia Katechizm Kościoła katolickiego oraz Kodeks Prawa Kanonicznego, deklarację Soboru Watykańskiego II Gravissimum educationis oraz papieskie encykliki i adhortacje: Divini illius Magistri Piusa XI, Humanae vitae Pawła VI, Familiaris consortio, Veritatis splendor oraz Evangelium vitae Jana Pawła II, Amoris laetitia papieża Franciszka. Obok dokumentów poświęconych w całości sprawie wychowania (GE, DIM) omówiono te, które podejmują temat fragmentarycznie (FC, AL), oraz te, które nie mówią wprost o wychowaniu, jednak poruszana w nich tematyka podstawowych wartości pośrednio stanowi niezbędne wezwanie i wskazówki wychowawcze (HV, VS, EV). Chociaż pochodzą one z okresu prawie dziwięćdziesięciu lat, widoczna jest spójność myśli wychowawczej opartej na Objawieniu Bożym. Synteza tematu wydaje się szczególnie potrzebna w obecnych czasach, kiedy przed rodzicami stają zupełnie nowe wyzwania, jeśli chodzi o szeroko rozumiane środowisko wychowania ich dzieci.

Słowa kluczowe: wychowanie; rodzina; wartości; wiara. 